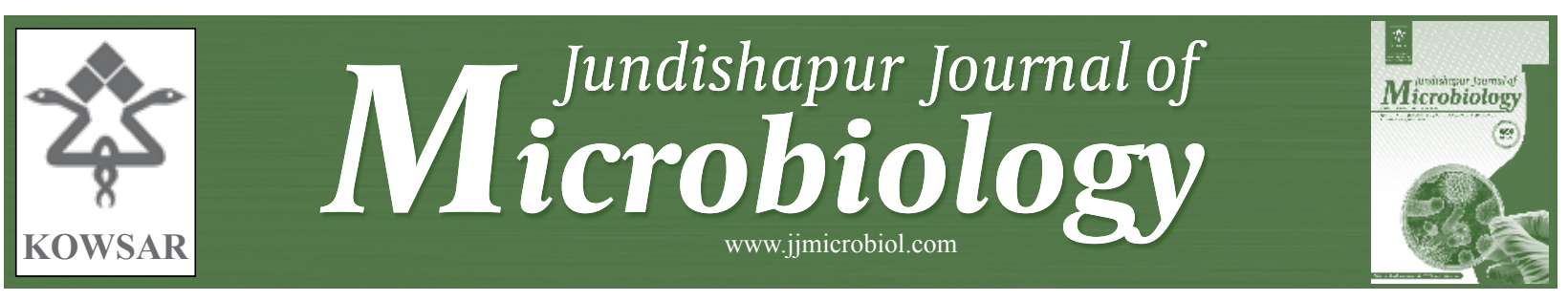

\title{
The Effect of Peganum harmala and Teucrium polium Alcoholic Extracts on Growth of Escherichia coli 0157
}

\author{
Mansour Mashreghi ${ }^{1,2}$, Soudabe Niknia ${ }^{1^{*}}$ \\ ${ }^{1}$ Department of Biology, Faculty of Sciences, Ferdowsi University of Mashhad, IR Iran \\ ${ }^{2}$ Cell and Molecular Biotechnology Research Group, Institute of Biotechnology, Ferdowsi University of Mashhad, IR Iran
}

A R T I C L E I N F O

Article type:

Original Article

Article history:

Received: 26 Jul 2011

Revised: 23 Nov 2011

Accepted: 01 Dec 2011

\section{Keywords:}

Peganum harmala

Teucrium polium

Escherichia coli 0157

Medicinal Plants

\begin{abstract}
A B S T R A C T
Background: Several medicinal plants have been used by humans for their vast diversity in chemical compound content and antimicrobial activity. However, their appropriate use remains under investigation by many researchers.

Objectives: This study aimed to determine the stage at which Escherichia coli 0157 growth is more sensitive to certain concentrations of certain medicinal plants.

Materials and Methods: Alcoholic extracts of the aerial parts and seeds of Peganum harmala and Teucrium polium were prepared using standard methods. The effective concentration (0.15-0.4 mg/ml) was chosen, based on their zones of inhibition on plates that were inoculated with E. coli 0157 and plant extract and used to monitor bacterial growth by spectrophotometry.

Results: All concentrations of the aerial parts of T. polium extract and the seeds of P. harmala decreased the absorbance in the first several hours after inoculation, after which bacterial growth increased to normal levels. Compared with control, no significant differences on the effect of the aerial parts of P. harmala extract on bacterial growth were observed.

Conclusions: Based on the comparison of growth curves, higher concentrations effected greater inhibition. However, the effects of other concentrations of the plant extracts on bacterial growth should be investigated further, although their toxicity must be assessed before use.
\end{abstract}

Copyright $\odot 2012$ Kowsar Corp. All rights reserved.

- Implication for health policy/practice/research/medical education:

Two Iranian endemic plants P. harmala and T. polium were selected and inhibition effects of different concentrations of their alcoholic extract on growth phases of E. coli O157 was investigated.

Please cite this paper as:

Mashreghi M, Niknia S. The Effect of Peganum harmala and Teucrium polium Alcoholic Extracts on Growth of Escherichia coli O157. Jundishapur J Microbiol. 2012;5(3):511-5. DOI:10.5812/jjm.3665

\section{Background}

Medicinal plants were the first medicines and have been used since ancient times (1), and they continue to be used by various cultures around the world (2). All drugs from plants contain substances, such as alkaloidal con-

${ }^{*}$ Corresponding author: Soudabe Niknia, Department of Biology, Faculty of Sciences, Ferdowsi University of Mashhad, IR Iran. Tel: +98-5118762227, Fax: +98-5118762227; E-mail: soudabe.niknia@gmail.com

DOI:10.5812/jjm.3665

Copyright @2012 Kowsar Corp. All rights reserved. stituents; essential oils; phenols; unsaturated long-chain aldehydes; peptides; and ethanol-, methanol-, and butanol-soluble compounds with specific therapeutic activities $(1,3)$. The antibacterial activities of several species of plants have been reported by many researchers $(1,4,5)$. We investigated 2 plants, Peganum harmala and Teucrium polium, commonly called "Espand" and "Kalbpoureh," respectively, in Iran. Peganum harmala is a perennial herbaceous, glabrous plant that can grow to $30-100 \mathrm{~cm}$ and is distributed throughout the Middle East, North Africa, and Central Asia $(2,6)$. It is famous for its antimicrobial 
activities, due to certain compound, such as alkaloids that are found in its seeds and roots $(2,6,7)$. The smoke of its seeds is used traditionally as a disinfectant. Also, alkaloids in P. harmala seed have vasorelaxant, antihemosporidian, anticancer, antinociceptive, antitumor and antineoplastic, and antiprotozoal effects (8).

Teucrium polium is a durable, wild-growing, flowering grass plant that can grow to $10-30 \mathrm{~cm}$, has a callous white exterior, and abounds in southwestern Asia, Europe, and North Africa $(1,8)$. Like P. harmala, T. polium is famous for its antimicrobial activities, stemming from compounds, such as flavonoids and terpenoids, that are found in its aerial parts $(9,10)$. T. polium is well known for its diuretic, antipyretic, diaphoretic, antispasmodic, tonic, antiflammatory, antihypertensive, anorexic, analgesic, and antidiabetic properties. It also protects against ethanolinduced gastric mucosal damage $(92.8 \%)$ and has been reported to reduce nicotinamide adenine dinucleotide phosphate (NADPH)-initiated lipid peroxidation in rat liver microsomes (11).

P. harmala and T. polium are traditional medicinal plants that are used for many purposes, particularly in treating gastrointestinal problems. Escherichia coli that is an anaerobic bacterium commonly found in the mammalian intestinal tract (12), of which there are pathogenic strains, such as O157: H7, which causes significant human diseases, such as diarrhea, hemorrhagic colitis (HC), and hemolytic-uremic syndrome (HUS) $(13,14)$.

\section{Objectives}

The object of this study was to examine the antibacterial activities of alcoholic extracts of P. harmala and T. polium against E. coli $\mathrm{O} 157$.

\section{Materials and Methods}

\subsection{Plant Collections and Identifications}

P. harmala (Zygophylaceae) (Figure 1: left) was collected from hills around Mashhad (northeast of Khourasan state, Iran) between May and August, and T. poluim (Labiatae) (Figure 1: right) was collected from Birjand (southeast of Khourasan state, Iran) in July. Taxonomic identification was peformed by the Faculty of Science Herbarium, Ferdowsi University of Mashhad, Iran.

\subsection{Plant Extract Preparation}

The aerial parts of $P$. harmala and T. polium were dried for 8-10 days at room temperature and ground to a powder separately, as were $P$. harmala seeds. The powder was first tyndallized, dissolved in ethanol (ethanol:water $=8: 2, \mathrm{v} / \mathrm{v}$ ) and distilled under a vacuum for several hours at $82^{\circ} \mathrm{C}$. Finally, the ethanol was removed by evaporation.

\subsection{Bacterial Strain}

The E. coli strain 0157 NCTC1290 was a kind donation of Prof. Penington, University of Aberdeen, UK.

\subsection{Well Diffusion Assay}

To determine the effective concentration, inhibiton zones of ethanolic extracts of P. harmala and T. polium were examined against E. coli 0157 by well assay technique (15). Overnight cultures of E. coli 0157 were spread onto Mueller-Hinton agar (Merck, Germany), and various concentrations of extracts (P. harmala: seeds: 0.15, 0.2, 0.3, and $0.4 \mathrm{mg} / \mathrm{mL}$; aerial parts: $0.15,0.2,0.3$, and $0.4 \mathrm{mg} / \mathrm{ml}$; T. polium: $0.1,0.2,0.3$, and $0.4 \mathrm{mg} / \mathrm{mL}$ ) were added to the pits in the culture with $10 \mathrm{~mm}$ diameter and incubated at $37^{\circ} \mathrm{C}$ for $24 \mathrm{~h}$. Then, the diameter of the inhibitory zone was measured, and the corresponding effective concentration was selected for subsequent experiments.

\subsection{Spectrophotometeric Assay}

The growth curve of E. coli 0157 was drawn per standard methods $(16,17)$. Various amounts of plant extract $(0.15-$ $0.4 \mathrm{mg} / \mathrm{mL}$ ) were added to nutrient broth medium (Mer$\mathrm{ck}$, Germany), containing 1-mL bacterial inocula $\left(10^{8}\right.$ cells/
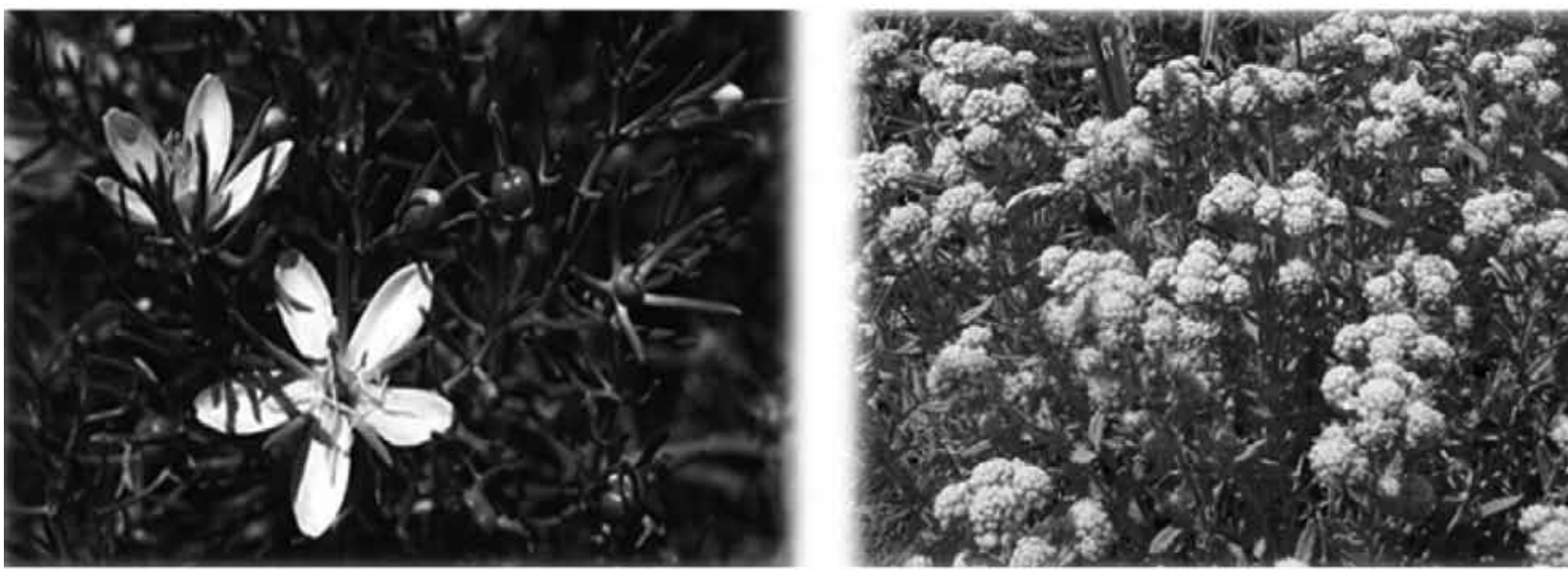

Figure 1. The Plants of This Study: Peganum harmala (Left), Teucrium polium (Right) 
$\mathrm{ml}$ ), by shaking the samples. The time-zero absorbance was read at $600 \mathrm{~nm}$ on a WPA Lightwave UV/Vis spectrophotmeter (Biochrom, UK). Subsequent absorbance readings were recorded in 1-hour intervals for $10 \mathrm{hrs}$. The results were transferred to Excel, and after mean absorbance values were calculated, logarithmic graphs were drawn and compared.

\section{Results}

Based on the inhibitory zone diameters (Figure 2 and Figure 3), the extract of seeds of P. harmala and T. polium at 0.3 $\mathrm{mg} / \mathrm{ml}$ had a greater inhibitory effect on E. coli 0157 than other concentrations. However, the aerial part extracts of P. harmala did not inhibit E. coli 0157 growth.

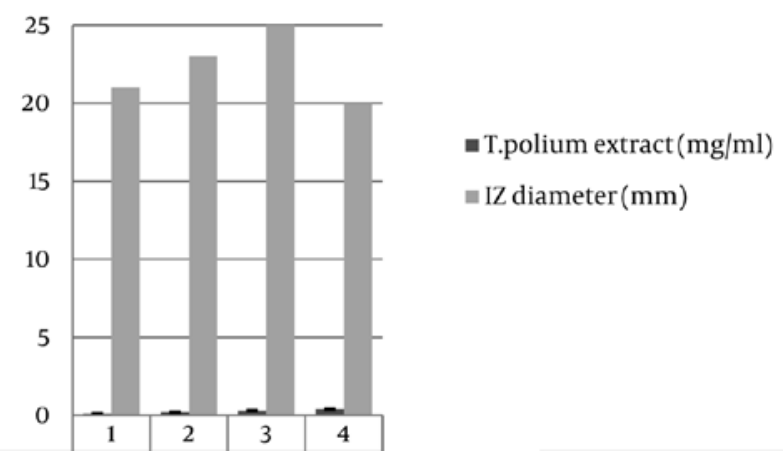

Figure 2. IZ Diameter of the Different Concentrations of T.polium Extract

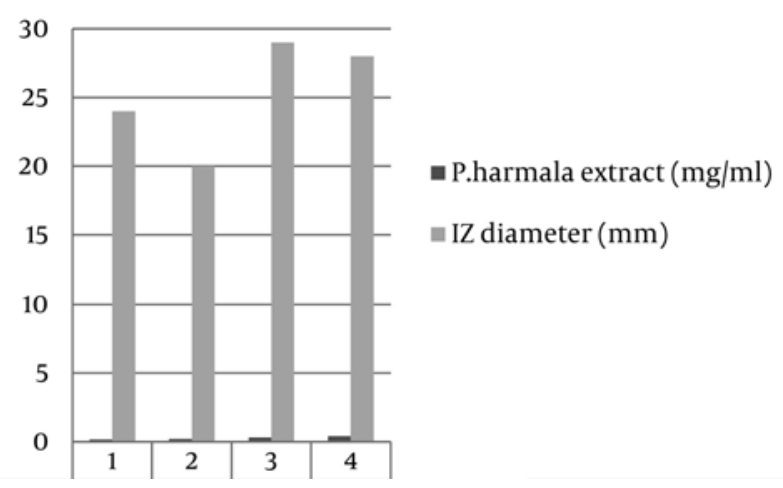

Figure 3. IZ Diameter of the Different Concentrations of $P$. harmala Extracts (Seeds)

By spectrophotometry, all concentrations (0.1, 0.2, 0.3 $\mathrm{mg} / \mathrm{ml}$ ) of the aerial parts of $T$. polium extract, reduced the absorbance (ie, growth) during the first several hours of inoculation, especially at Hour 2; the in the greatest decrease was effected by $0.3 \mathrm{mg} / \mathrm{ml}$ extract (Figure 4). From Hours 4 to 6 , the effects of the various concentrations were the same. At Hour 7, the greatest decline was observed with $0.2 \mathrm{mg} / \mathrm{ml}$ extract. At Hours 8 and 9, the effects of 0.2 and $0.3 \mathrm{mg} / \mathrm{ml}$ extract were equal, and at Hour 10, the absorbance increased with all concentrations $(0.1,0.2,0.3 \mathrm{mg} / \mathrm{ml})$ of the extract of the aerial parts of T.polium .

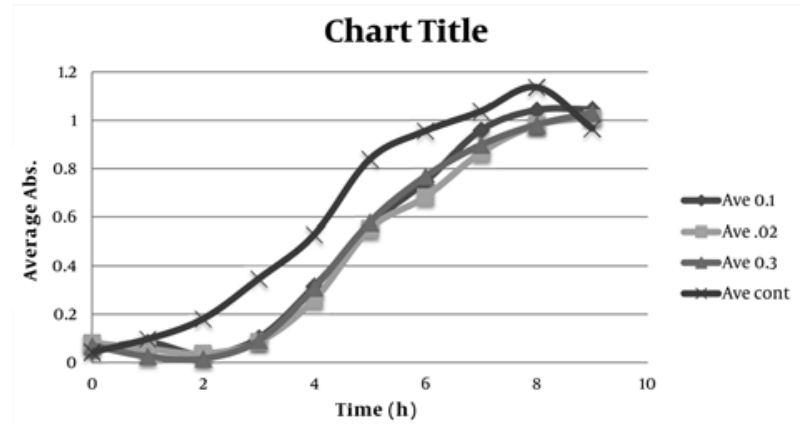

$\overline{\text { Figure 4. Changes in E. coli O157 Growth (Abs) at Presence of Different Con- }}$ centrations of Alcoholic Extract of Teucrium polium

With all concentrations $(0.15,0.2,0.3 \mathrm{mg} / \mathrm{mL})$ of the extract of P. harmala seeds, the absorbance (Figure 5) decreased in the first several hours of inoculation, especially Hour 2; the greatest declined occurred at $0.15 \mathrm{mg} /$ $\mathrm{mL}$. The effect of $0.3 \mathrm{mg} / \mathrm{ml}$ extract was more robust than with other concentrations at Hours 3 to 10. In the 11th hour, the absorbance did not decrease at any concentration $(0.15,0.2,0.3 \mathrm{mg} / \mathrm{mL})$ of $P$. harmala seed extract and was similar to that of the control.

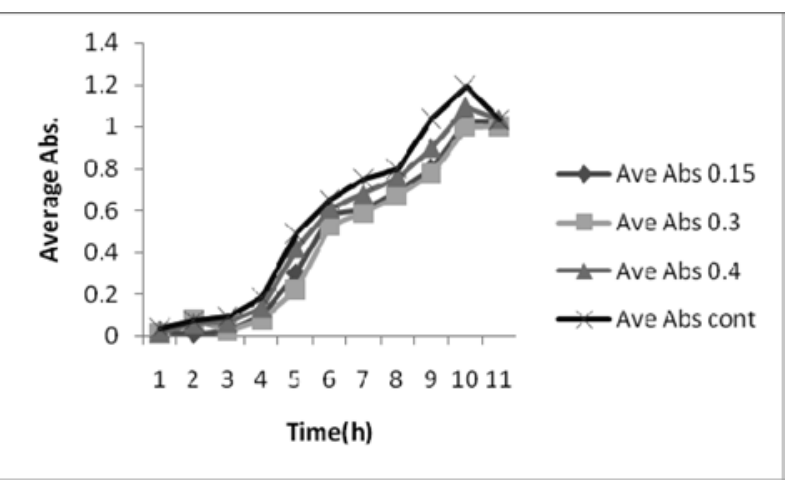

Figure 5. Changes in E. coli O157 Growth (Abs) at Presence of Different Concentrations of Alcoholic Extract of Peganum harmala (Seeds)

By spectrophotometry, there was no inhibition with 0.2, 0.3 , or $0.4 \mathrm{mg} / \mathrm{ml}$ of the extract of the aerial parts of $P$. harmala against E. coli O157 (Figure 6).

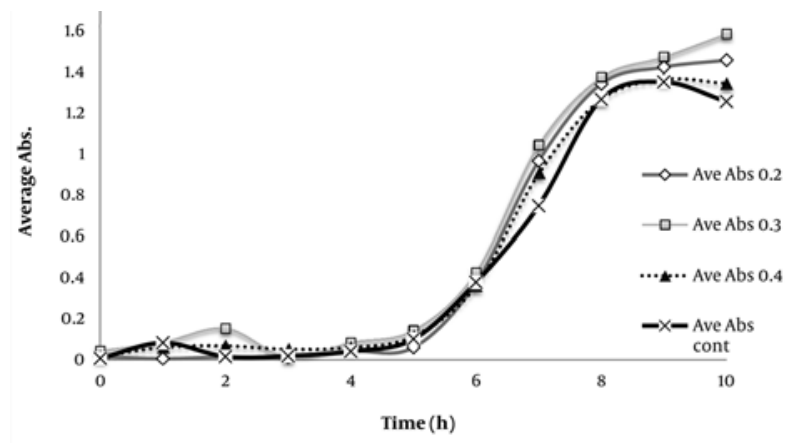

Figure 6. Changes in E. coli 0157 Growth (Abs) at Presence of Different Concentrations of Alcoholic Extract of Peganum harmala (the Aerial Parts) 
At $0.3 \mathrm{mg} / \mathrm{ml}$, the extracts of the aerial parts of T. polium and the seeds of $P$. harmala extract effected the greatest inhibition of various growth phases of E. coli 0157.

\section{Discussion}

Historically, plants have been a good source of new drug compounds (18). Today, in many parts of the world, the extracts of medicinal plants are used for their antibacterial, antifungal, and antiviral properties $(4,5,19)$. In Iran, the use of these natural resources goes back to its origins, and many reports on this topic exist (20). Some groups have reported that there is a relationship between the chemical compounds and the antimicrobial activity of plants (1). Yet, the antibacterial properties of such plants are poorly understood and remain under debate $(21,22)$. Therefore, an investigation of the antibacterial properties of plants, especially endemic plants, could have a benefit finding identifying an effective species that controls the growth of an important bacterial pathogen.

An ethanolic $P$. harmala extract has been shown to have high antibacterial activity against MRSA (methicillinresistant Staphylococcus aureus) (23) and CRSA (cefiximeresistant S. aureus) (24).

Also, an ethanolic T. polium extract has high antibacterial activity against certain bacteria, such as TRBM (tetracycline-resistant Brucella melitensis) (25), E. coli, and Salmonela Typhi (26).

The antibacterial effects of 3 plants (Vitex angus castus, Eucalyptus globules, and Juglans regia) (27) have been examined, wherein E. coli was killed by Vitex angus castus extract at $0.2 \mathrm{mg} / \mathrm{ml}$. Of 38 commonly used medicinal plant species in Thailand, the aqueous and ethanolic extracts of Quercus infectoria and the aqueous extract of Punica granatum were highly effective against Escherichia coli 0157 with peak MIC and MBC values of 0.09 and $0.19 \mathrm{mg} / \mathrm{ml}$, respectively (14).

Based on these findings, 2 medicinal plants-P. harmala and T. polium-were chosen for this study. Traditionally, they are used to treat gastrointestinal problems. P. harmala has some alkaloids and harmalol-quinazoline derivatives that provide its pharmacological activity (2). T. polium has flavonoids that are widespread in the plant kingdom and have many functions, including anti-inflammatory, antimicrobial, enzyme inhibitory, antioxidant, and antitumor activities $(10,28,29)$. We use spectrophotometry, because cell biomass (turbidity) is gives a better and more rapid indication of the concentrations of plant extracts that have a greater effect on bacterial growth. The absorbance of turbid samples, such as cell cultures, is based on to light scatter, not molecular absorption. In the first hour of bacterial growth, the absorbance decreased and $\mathrm{T} \%$ increased at all concentrations, demonstrating that the alcoholic extracts of $P$. harmala and T. polium inhibit the growth of E. coli 0157 in the early stages of its growth.

Cells were more vulnerable to the inhibitory effects of plant extracts during exponential growth versus other growth phases. In the comparison of growth curves, higher concentrations had a greater effect.

A comparison of the 3 extracts showed that T. polium effected greater inhibition of E. coli O157,a major gastrointestinal pathogenic microbe. However, with regard to medical prescription, the toxicity of higher concentrations must be checked before administration.

In this study, the absorbance and $\mathrm{T} \%$ curves of the extracts of T. polium and the seeds of $P$. harmala showed their effective antimicrobial effects against bacteria that cause gastrointestinal problems, especially at the early stage of growth.

\section{Acknowledgements}

The authors would like to thank the Microbiological laboratory of Ferdowsi university of Mashhad and Mrs. Sedighe Molaei and Mrs. Hanie Shariatmadari for their assistances to complete the work and Miss Masoume Esmaeili nezhad and Miss Soraya Ebrahimi for their assistances to complete the graphs.

\section{Financial Disclosure}

None Declared.

\section{Funding/Support}

This research was supported by Research Deputy of Ferdowsi University of Mashhad, Iran (grant no: 40839).

\section{References}

1. Seyyednejad S, Motamedi H. A review on native medicinal plants in Khuzestan, Iran with antibacterial properties. Int J Pharmacol. 2010;6(5):551-60.

2. Mahmoudian M, Jalilpour H, Salehian P. Toxicity of Peganum harmala: review and a case report. Iranian J Pharmacol Th. 2002;1(1):14.

3. Serrentino J, Point Robert WA. How Natural Remedies Work. Harley and Marks Publishers; 1991. p. 20 -2.

4. Özcan M, Erkmen O. Antimicrobial activity of the essential oils of Turkish plant spices. Eur Food Res Technol. 2001;212(6):658-60.

5. SaDdıç O, Özcan M. Antibacterial activity of Turkish spice hydrosols. Food Control. 2003;14(3):141-3.

6. Shamsa F, Monsef HR, Ghamoosh R, Verdian MR. Spectrophotometric determination of total alkaloids in Peganum harmala $\mathrm{L}$. using Bromocresol Green. Res J Phytochem. 2007;1:79-82.

7. Mirzaie M, Nosratabadi SJ, Derakhshanfar A, Sharif I. Antileishmanial activity of Peganum harmala extract on the in vitro growth of Leishmania major promastigotes in comparison to a trivalent antimony drug. Veterinarski arhiV. 2007;77(4):365.

8. Arshad N, Neubauer C, Hasnain S, Hess M. Peganum harmala Can Minimize Escherichia coli Infection in Poultry, but Long-Term Feeding May Induce Side Effects. Poultry Science. 2008;87(2):2409.

9. Hasani P, Yasa N, Vosough-Ghanbari S, Mohammadirad A, Dehghan G, Abdollahi M. In vivo antioxidant potential of Teucrium polium, as compared to alpha-tocopherol. Acta Pharm. 2007;57(1):123-9.

10. Talib WH, Mahasneh AM. Antimicrobial, cytotoxicity and phytochemical screening of Jordanian plants used in traditional medicine. Molecules. 2010;15(3):1811-24.

11. Mehrabani D, Rezaee A, Azarpira N, Fattahi MR, Amini M, 
Tanideh N, et al. The healing effects of Teucrium polium in the repair of indomethacin-induced gastric ulcer in rats. Saudi Med J. 2009;30(4):494-9.

12. Drasar Bs, Barrow PA. Intestial Microbiology. American Society for Microbiology Press, Washington, Dc;1985.

13. Callaway TR, Carr M, Edrington T, Anderson RC, Nisbet DJ. Diet, Escherichia coli O157: H7, and cattle: a review after 10 years. Mol Biol. 2009;11(2):67-80.

14. Voravuthikunchai S, Lortheeranuwat A, Jeeju W, Sririrak T, Phongpaichit S, Supawita T. Effective medicinal plants against enterohaemorrhagic Escherichia coli O157:H7.J Ethnopharmacol. 2004;94(1):49-54.

15. Forbes BA, Sahm DF, Weissfeld AS, Trevino EA. Methods for testing antimicrobial effectiveness. In: Bailey and Scott's Diagnostic Microbiology. Eds E.J. Baron, L.R. Peterson and S.M. Finegold), Mosby Co: St Louis, Missouri; 1990

16. Cornu M, Delignette-Muller ML, Flandrois JP. Characterization of unexpected growth of Escherichia coli O157:H7 by modeling. Appl Environ Microbiol. 1999;65(12):5322-7.

17. Smith RP, Baltch AL, Michelsen PB, Ritz WJ, Alteri R. Use of the Microbial Growth Curve in Postantibiotic Effect Studies of Legionella pneumophila. Antimicrob Agents Chemother. 2003;47(3):1081-7.

18. El Astal Z, Ashour A, Kerrit A. Antimicrobial activity of some medicinal plant extracts in Palestine. PakJ Med Sci. 2005;21(2):187-93.

19. Hassawi D, Kharma A. Antimicrobial activity of some medicinal plants against Candida albicans.J Biol Sci. 2006;6(1):109.

20. Lothfipour F, Nazemiyeh H, Fathi-Azad F, Garaei N, Arami S. Evaluation of antibacterial activities of some medicinal plants from north-west Iran. Iran J Basic Med Sci. 2008;11(2):80-5.

21. Okemo P, Mwatha W, Chhabra S, Fabry W. The kill kinetics of Aza- dirachta indica A. Juss.(Meliaceae) extracts on Staphylococcus aureus, Escherichia coli, Pseudomonas aeruginosa and Candida albicans. African J Sci Techol. 2001;2(2):113-8.

22. Zakaria Z, Sreenivasan $S$, Mohamad M. Antimicrobial activity of Piper ribesoides root extract against Staphylococcus aureus. J Appl Biol Sci. 2007;1(3):87-90.

23. Moghadam MS, Maleki S, Darabpour E, Motamedi H, seyyednejad SM. Antibacterial activity of eight local plant extracts in Khouzestan, Iran against methicillin and cefixime resistant Staphylococcous aureus strains. Asian pacific J Trop Med. 2010;3:262-3.

24. Prashanth D, John S. Antibacterial activity of Peganum harmala. Fitoterapia. 1999;70(4):438-9.

25. Motamedi H, Darabpour E, Gholipour M, Seyyednejad SM. Antibacterial effect of ethanolic and methanolic extracts of Plantago ovate and Oliveria decumbens endemic in Iran against some pathogenic bacteria. Int J Pharmacol. 2010;6:117-22.

26. Darabpour E, Gholipour M, Motamedi H, Seyyednejad SM. Antimicrobial properties of Teucrium polium, endemic in Khuzestan province, IRAN, against some clinical pathogens. Asian Pacific J Trop Med. 2010;3:124-7.

27. Mashreghi M, Molaei S, Gholami Z, Tavalaei S. Investigation of effect of alcoholic extract of three plants in Khorasan on different growth phases of E. coli 0157 by spectrophotometric method. Komesh. 2007:23:145-53.

28. Harborne JB, Tomás-Barberán FA, Williams CA, Gil MI. A chemotaxonomic study of flavonoids from european teucrium species. Phytochemistry. 1986;25(12):2811-6.

29. Rizk A, Hammouda F, Rimpler H, Kamel A. Iridoids and flavonoids of Teucrium polium herb. Planta medica. 1986;2:87-8. 